\title{
The organizational component of the mechanism of investment development
}

\author{
Elena Semenova ${ }^{1, *}$ \\ ${ }^{1}$ Federal Research Center of Agrarian Economy and Social Development of Rural Areas - All \\ Russian Research Institute of Agricultural Economics, 123007, Khoroshevskoye shosse, 35k2, \\ Moscow, Russia
}

\begin{abstract}
The organizational and economic mechanism includes the organizational and economic blocks. The article considers the elements of the organizational component of the investment development mechanism the size of the organization, the organizational and legal form and the specialization of the organization, which influence the investment development of the industry. The research was carried out on the basis of the official accounting statements of organizations of the Russian Federation for 2016 of the database of the Federal State Statistics Service of the Russian Federation using the software of the consulting financial and analytical company Akon. Groups of agricultural organizations were identified by type of activity. It is concluded that small forms of enterprises prevail in the sectors of dairy and beef cattle breeding, and potato farming that determines their lower profitability and limits the possibilities for investing at their own funds. In specialized large and medium-sized organizations (production of grain and oilseeds, and sugar beet production) the efficiency of production is higher against the mixed production. The predominantly joint-stock form of management among large and medium-sized agricultural organizations expands the possibilities of investment activity.
\end{abstract}

\section{Introduction}

From a microeconomic point of view, the investment theory considers the investment decision-making process at the level of organizations on the basis of applying scientifically grounded methods of forming an optimal investment policy. From a macroeconomic position it is focused on the formation of state investment policy, income and employment policies.

The organizational and economic mechanism of the investment development is a set of forms (links) and methods for implementing investment activities that are interrelated and coordinated and thus provide investment in the industry. There are two main blocks in the organizational and economic mechanism: organizational and economic ones.

The organizational component includes the form of enterprises, specialization, the size of the organization, the development of entrepreneurship, planning, the management system, production technology, etc. Each of these elements will influence the opportunities for investment development of the industry.

*Corresponding author: esemenova@bk.ru 
The economic block covers financing and crediting of organizations, participating in the investment process, taxation, insurance of organizations, stimulation of the development of the investment process, pricing, etc.

The purpose of the study is to analyze the organizational component of the organizational and economic mechanism of the investment development in agricultural production, and its impact on the investment process.

\section{Research methods}

The research is carried out on the basis of the official accounting statements of the organizations of the Russian Federation for 2016 of the database of the Federal State Statistics Service of the Russian Federation (2.3 million organizations) using the software of the consulting financial and analytical company Akon. Financial ratios for groups of organizations correspond to the median value of the indicators of all organizations of the Russian Federation and organizations within the framework of the sub-sectors and activities compared.

\section{Results}

Different assets, property, real estate, securities, shares, and cash can be the funds for investment. Let us consider investment opportunities for agricultural organizations at their own funds.

The Table 1 shows the grouping of organizations by type, scale of activity and specialization, which shows that by types of the agricultural activity, large organizations with revenues from 2 billion rubles prevail in pig breeding (9.68\%), poultry (11.76\%), and sugar beet cultivation $(8.16 \%)$. In general, in Russia such organizations make up $0.5 \%$. Mediumsized organizations with a size of revenues of 800-2000 million rubles also have the largest share in these industries.

Thus, $16.32 \%$ of the organizations that grow sugar beets, $23.93 \%$ of poultry organizations, and $18.3 \%$ of pig-breeding organizations can make investments at their own expense, since they have significant revenues.

The Table 1 presents specialized organizations by type of activity and mixed organizations, in which crop production in combination with livestock farming without specialized production of crops or animals is developed. These are the organizations whose gross profit from crop or livestock production is less than $66 \%$ of the standard gross profit [2]. Among the mixed organizations, microenterprises $(41.71 \%)$ and nano-enterprises $(43.43 \%)$ predominate, which cannot implement large investment projects due to the lack of own funds and low revenues. The situation is similar in the meat cattle breeding and potato growing. 
Table 1. Characteristics of organizations by type, scale of activity and specialization, 2016.

\begin{tabular}{|c|c|c|c|c|c|c|c|c|c|c|}
\hline Category of organizations & \multicolumn{2}{|c|}{ Large } & \multicolumn{2}{|c|}{ Medium-sized } & \multicolumn{2}{|c|}{ Small } & \multicolumn{2}{|c|}{ Micro } & \multicolumn{2}{|c|}{ Nano } \\
\hline $\begin{array}{l}\text { Scale of activity - revenue in } \\
\text { million rubles }\end{array}$ & \multicolumn{2}{|c|}{ More than 2000} & \multicolumn{2}{|c|}{$800-2000$} & \multicolumn{2}{|c|}{$120-800$} & \multicolumn{2}{|c|}{$10-120$} & \multicolumn{2}{|c|}{ Less than 10} \\
\hline By type of activity: & $\begin{array}{c}\text { Number of } \\
\text { units }\end{array}$ & Share, $\%$ & $\begin{array}{c}\text { Number of } \\
\text { units }\end{array}$ & $\begin{array}{c}\text { Share, } \\
\%\end{array}$ & $\begin{array}{l}\text { Number of } \\
\text { units }\end{array}$ & $\begin{array}{c}\text { Share, } \\
\%\end{array}$ & $\begin{array}{l}\text { Number of } \\
\text { units }\end{array}$ & $\begin{array}{c}\text { Share, } \\
\%\end{array}$ & $\begin{array}{c}\text { Number of } \\
\text { units }\end{array}$ & $\begin{array}{c}\text { Share, } \\
\%\end{array}$ \\
\hline 01.11.1 "Growing cereals" & 16 & 0.23 & 90 & 1.29 & 1030 & 14.78 & 3150 & 45.19 & 2670 & 38.31 \\
\hline 01.11.3 "Growing oil seeds" & 2 & 1.04 & 3 & 1.55 & 20 & 10.36 & 80 & 41.45 & 88 & 45.60 \\
\hline 01.13.1 "Growing vegetables" & 4 & 0.47 & 12 & 1.41 & 80 & 9.38 & 262 & 30.72 & 358 & 41.97 \\
\hline 01.13.31 "Growing potatoes" & 0 & 0.00 & 0 & 0.00 & 7 & 10.94 & 12 & 18.75 & 43 & 67.19 \\
\hline $\begin{array}{l}01.13 .51 \text { "Growing sugar } \\
\text { beets" }\end{array}$ & 4 & 8.16 & 4 & 8.16 & 16 & 32.65 & 19 & 38.78 & 6 & 12.24 \\
\hline $\begin{array}{l}01.41 \text { "Breeding of dairy } \\
\text { cattle, production of raw } \\
\text { milk" }\end{array}$ & 5 & 0.16 & 16 & 0.52 & 360 & 11.73 & 1217 & 39.64 & 1472 & 47.95 \\
\hline $\begin{array}{l}01.42 .1 \text { "Breeding of meat } \\
\text { and other cattle, including } \\
\text { buffaloes, yaks, etc." }\end{array}$ & 0 & 0.00 & 0 & 0.00 & 3 & 5.66 & 26 & 49.06 & 24 & 45.28 \\
\hline $\begin{array}{l}01.47 \text { "Breeding of } \\
\text { agricultural poultry" }\end{array}$ & 58 & 11.76 & 60 & 12.17 & 105 & 21.30 & 97 & 19.68 & 173 & 35.09 \\
\hline 01.46 "Pig farming" & 31 & 9.78 & 27 & 8.52 & 73 & 23.03 & 66 & 20.82 & 120 & 37.85 \\
\hline 01.50 "Mixed agriculture" & 13 & 0.93 & 7 & 0.50 & 184 & 13.14 & 584 & 41.71 & 608 & 43.43 \\
\hline $\begin{array}{l}\text { All organizations of Russia, } \\
\text { thousand units }\end{array}$ & 9 & 0.5 & 14 & 0.9 & 109 & 7.2 & 513 & 34.8 & 670 & 56.3 \\
\hline
\end{tabular}


The result of the specialization is an increase in the volume and quality of products, an increase in labor productivity, a reduction in the production costs, and an increase in profitability. The economic efficiency of specialization can be estimated by the indicator of profitability.

Table 2. Indicators of profitability by type of activity.

\begin{tabular}{|c|c|c|c|c|c|c|c|}
\hline & 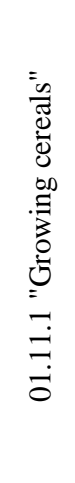 & 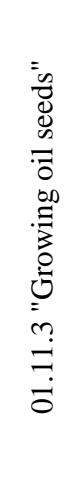 & 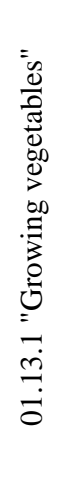 & 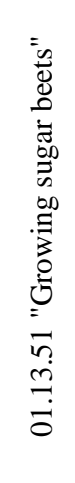 & 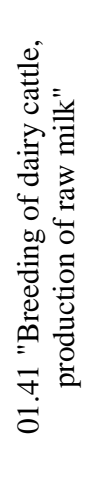 & 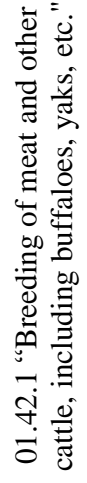 & 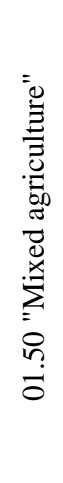 \\
\hline $\begin{array}{l}\text { Profitability of } \\
\text { sales }\end{array}$ & 18.1 & 19.3 & 0.3 & 25.7 & 4.4 & 5.1 & 7.1 \\
\hline Net profit margin & 16.3 & 17.1 & 4.6 & 20 & 6.8 & 4.6 & 8.7 \\
\hline Return on assets & 10.5 & 13.2 & 1.5 & 12.7 & 4 & 1.3 & 5.6 \\
\hline
\end{tabular}

Sugar beet, oilseeds and grain crops enterprises have the highest profitability of sales. The activities of these organizations in general are also efficient, since the rate of net profit is high. The return on assets shows the return on the invested ruble to the assets of the organization. The highest return is on oilseeds - 13.2 kopecks, and on sugar beet - 12.7 kopecks. Compared with organizations with mixed farming, the specialized farms for growing grain crops, oilseeds, and sugar beet have almost twice as high efficiency indicators, which confirms the efficiency of the specialized production, and creates opportunities for investing own means in these industries. In the organizations growing potatoes, small forms of enterprises, as well as a manual labor and a low level of mechanization prevail, that reduces the effect of specialization. Meat and dairy cattle have a high proportion of small forms of enterprises.

The Table 3 presents the ratings of organizations (Top-10) by revenue and activities. Even among 10 leading organizations of one type of activity, the gap in revenues is 39.2 times for mixed agricultural organizations (the leader is "Agro-complex" named after N.I. Tkachev, JSC), 15.4 times - for sugar beet organizations (the leader is "Rusagroinvest", LLC). At the same time, for all organizations of Russia, the gap in the Top-10 in terms of revenue is 27.4 times (the leader is VTB Capital, JSC), that indicates the hypertrophied development of individual agricultural organizations or miscalculations in the agrarian policy. 
Table 3. Top-10 by the type of activity by revenue, 2016, million rubles.

\begin{tabular}{|c|c|c|c|c|c|c|c|c|c|c|}
\hline 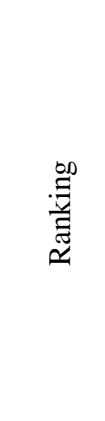 & 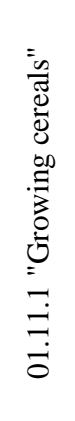 & 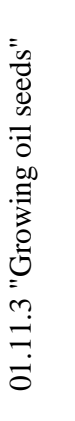 & 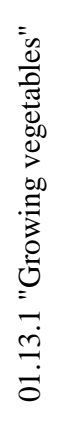 & 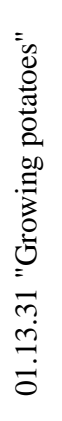 & 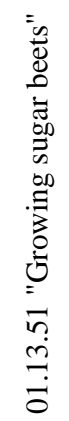 & 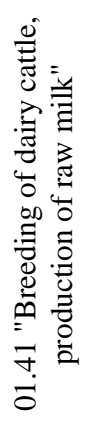 & 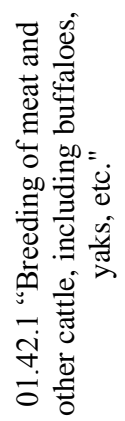 & 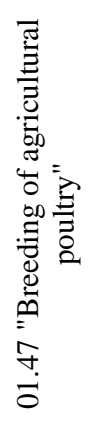 & 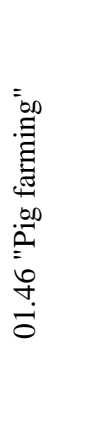 & 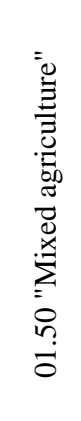 \\
\hline 1 & 7502 & 5411 & 3697 & 492 & $\begin{array}{c}1170 \\
4\end{array}$ & 3829 & 504 & 35079 & 45205 & 44756 \\
\hline 2 & 4839 & 2017 & 3047 & 315 & 6989 & 3700 & 219 & 23822 & 16317 & 3934 \\
\hline 3 & 3855 & 1010 & 2960 & 199 & 5170 & 3258 & 124 & 23546 & 15876 & 3378 \\
\hline 4 & 3843 & 922 & 2947 & 190 & 2955 & 2367 & 116 & 19305 & 14738 & 1569 \\
\hline 5 & 3593 & 804 & 1585 & 188 & 1659 & 2362 & 114 & 11284 & 8081 & 1464 \\
\hline 6 & 3414 & 704 & 1555 & 165 & 1415 & 1930 & 92,7 & 10325 & 5998 & 1440 \\
\hline 7 & 2996 & 632 & 1539 & 138 & 1265 & 1886 & 89,0 & 10115 & 5669 & 1420 \\
\hline 8 & 2836 & 597 & 1457 & 114 & 824 & 1568 & 69,9 & 9083 & 5374 & 1410 \\
\hline 9 & 2813 & 583 & 1340 & 109 & 771 & 1395 & 62,7 & 8360 & 5263 & 1276 \\
\hline 10 & 2643 & 527 & 1310 & 99,1 & 762 & 1216 & 60,9 & 8261 & 4986 & 1142 \\
\hline $\begin{array}{l}\text { Place } \\
10 \text { to } 1 \text {, } \\
\text { time }\end{array}$ & 2.8 & 10.3 & 2.8 & 5.0 & 15.4 & 3.1 & 8.3 & 4.2 & 9.1 & 39.2 \\
\hline
\end{tabular}

Enterprises of various organizational and legal forms have different opportunities to attract investment: in joint-stock companies it is done through corporatization, in a limited partnership - by the contributing members, in cooperatives - by the share contributions. In peasant (private) farms and individual entrepreneurial activities, the difficulty in accumulating sufficient financial resources for investing them in expanding production and modernization is one of the main shortcomings for investment. For small forms of enterprises, it is difficult enough to grow into a large organization at the expense of own funds. An open joint-stock company has greater opportunities to attract capital from external sources.

Since investment activity is a type of entrepreneurial activity, it is connected with forms of ownership. Depending on the existing forms of ownership and organizational and legal forms of enterprises, investment activity can be carried out in the form of state investment, investment by citizens and legal entities, foreign investment, and joint investment. The Table 4 shows the distribution of organizations by organizational and legal forms and activities. For the analysis, the first one hundred organizations in the rating were selected for each type of activity, i.e. mainly large and medium-sized organizations. 
Table 4 Distribution of organizations by organizational and legal form, and types of activity.

\begin{tabular}{|c|c|c|c|c|c|c|}
\hline \multirow[b]{2}{*}{ Type of activity } & \multicolumn{5}{|c|}{ Legal form } & \multirow[b]{2}{*}{ Peasant farm } \\
\hline & $\begin{array}{l}\text { Joint stock } \\
\text { company, } \\
\text { public } \\
\text { company }\end{array}$ & $\begin{array}{c}\text { Open } \\
\text { Company }\end{array}$ & $\begin{array}{c}\text { Production } \\
\text { cooperative, } \\
\text { artel, collective } \\
\text { farm }\end{array}$ & $\begin{array}{l}\text { State unitary } \\
\text { enterprise }\end{array}$ & $\begin{array}{l}\text { National } \\
\text { enterprise }\end{array}$ & \\
\hline $\begin{array}{l}01.11 .1 \text { "Growing } \\
\text { cereals" }\end{array}$ & 28 & 66 & 3 & 2 & 1 & - \\
\hline $\begin{array}{l}01.11 .3 \text { "Growing oil } \\
\text { seeds" }\end{array}$ & 7 & 71 & 14 & 1 & 1 & 6 \\
\hline $\begin{array}{l}01.13 .1 \text { "Growing } \\
\text { vegetables" }\end{array}$ & 32 & 58 & 6 & 4 & - & - \\
\hline $\begin{array}{l}01.13 .31 \text { "Growing } \\
\text { potatoes" }\end{array}$ & 7 & 27 & 19 & - & - & 11 \\
\hline $\begin{array}{l}01.13 .51 \text { "Growing } \\
\text { sugar beets" }\end{array}$ & 4 & 38 & 4 & - & - & 3 \\
\hline $\begin{array}{l}01.41 \text { "Breeding of } \\
\text { dairy cattle, } \\
\text { production of raw } \\
\text { milk" }\end{array}$ & 37 & 48 & 14 & 1 & - & - \\
\hline $\begin{array}{l}01.42 .1 \text { "Breeding of } \\
\text { meat and other cattle, } \\
\text { including buffaloes, } \\
\text { yaks, etc." }\end{array}$ & 3 & 35 & 12 & 1 & & 2 \\
\hline $\begin{array}{l}01.47 \text { "Breeding of } \\
\text { agricultural poultry" }\end{array}$ & 61 & 38 & 1 & - & - & - \\
\hline 01.46 "Pig farming" & 30 & 66 & 4 & - & - & - \\
\hline $\begin{array}{l}01.50 \text { "Mixed } \\
\text { agriculture" }\end{array}$ & 28 & 57 & 15 & - & - & - \\
\hline
\end{tabular}

It can be concluded that among large and medium-sized organizations, the joint stock form prevails that corresponds to the structure of agricultural organizations by forms of management in the country as a whole: open joint stock companies - 3.3\%; closed joint stock companies $-4.3 \%$, limited companies (limited partnerships) - 57.5, agricultural cooperatives - 21.1 and state organizations - $1.9 \%$ [3].

To determine the possibilities of investment, it is advisable to consider a number of financial ratios by types of activity that investors pay attention to.

The average values of the financial state of organizations by type of activity correspond to the median. The average values of the first four financial ratios for all analyzed organizations correspond to the standard values that indicate the independence of the aggregate of organizations from the borrowed sources of financing and the adequacy of funds for financing current activities. Coefficient of investment cover testifies of the possibility of settling with creditors, but for all types of activities, except grain crops, it has a boundary value. The financial indicators of beef cattle-breeding organizations are close to the threshold values.

The ratio of quick liquidity is lower than the normative value for all organizations (except beet-growing), and there is a risk of loss of solvency. Absolute liquidity ratio does not correspond to the norm for all organizations that is determined by the specifics of the production cycle in agriculture.

However, we have to note that these are average values of financial ratios, and the analysis of the activities of each particular organization is necessary.

Table 5. Financial condition of the organizations of various types of activities. 


\begin{tabular}{|c|c|c|c|c|c|c|c|c|}
\hline & 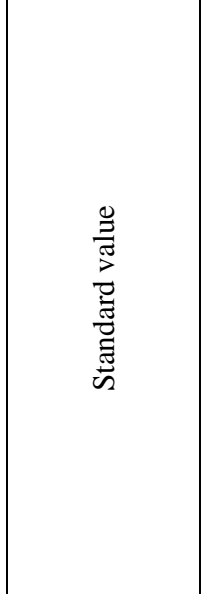 & 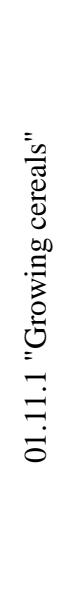 & 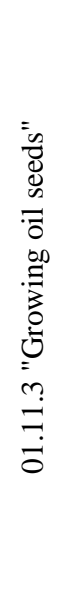 & 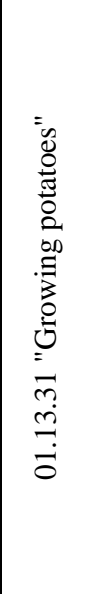 & 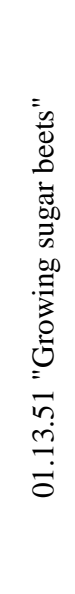 & 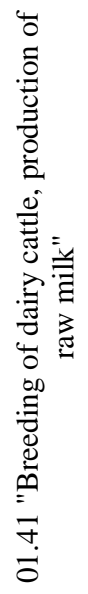 & 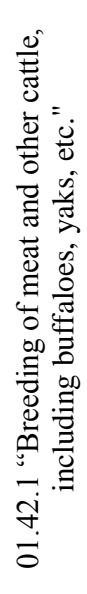 & 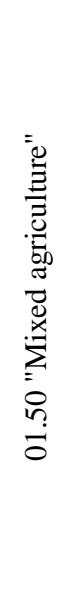 \\
\hline $\begin{array}{l}\text { 1. Coefficient of autonomy } \\
\text { (financial independence) }\end{array}$ & $\begin{array}{c}\geq 0.5 \text { (optimally } \\
0.6-0.7) .\end{array}$ & 0,8 & 0,7 & 0,6 & 0,7 & 0,7 & 0,5 & 0,7 \\
\hline $\begin{array}{l}\text { 2. Ratio of self-sufficiency in } \\
\text { working capital }\end{array}$ & hot less than 0.1 & 0,5 & 0,5 & 0,3 & 0,4 & 0,3 & 0,1 & 0,3 \\
\hline $\begin{array}{l}\text { 3. Coefficient of investment } \\
\text { cover }\end{array}$ & $\begin{array}{l}\geq 1(\text { not less } \\
\text { than } 0.7-0.8))\end{array}$ & 0,9 & 0,8 & 0,8 & 0,7 & 0,8 & 0,7 & 0,8 \\
\hline $\begin{array}{l}\text { 4. Coefficient of current } \\
\text { liquidity }\end{array}$ & $\begin{array}{c}\geq 2 \text { (by industry } \\
\text { up to } 1.5 \text { ) }\end{array}$ & 4,1 & 3 & 2,1 & 2 & 2,4 & 2 & 2.2 \\
\hline 5. Quick liquidity ratio & $\geq 1$ & 0,8 & 0,7 & 0,5 & 1,4 & 0,5 & 0,5 & 0,4 \\
\hline 6. Absolute liquidity ratio & $\geq 0.2$ & 0,1 & 0,1 & 0,007 & 0,07 & 0,03 & 0,06 & 0,02 \\
\hline
\end{tabular}

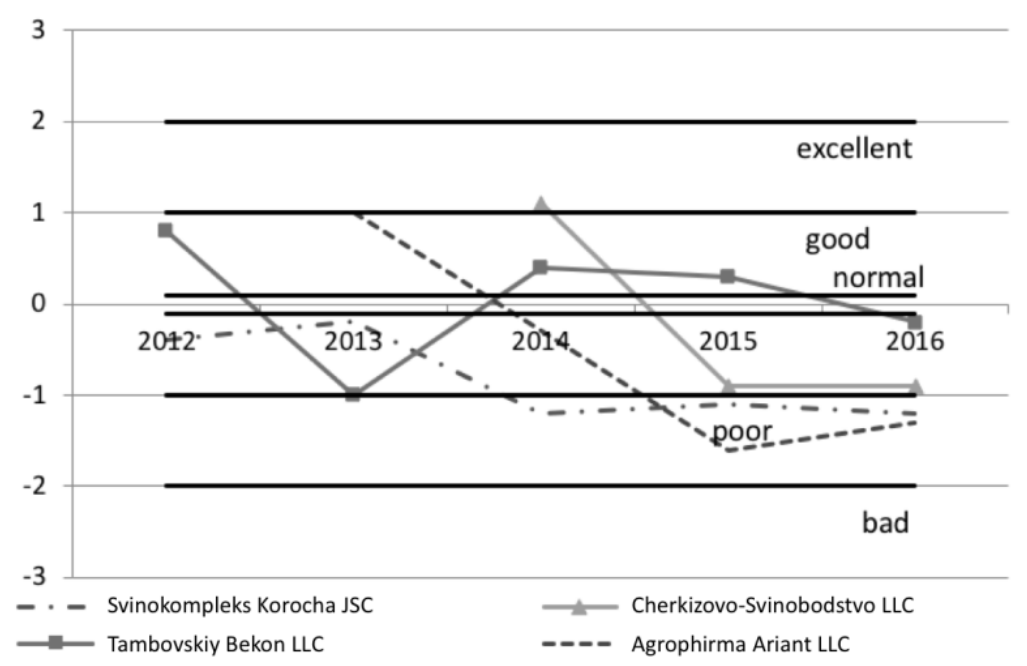

Fig. 1. Dynamics of the integral indicator of the financial state of the leading organizations by the type of activity 01.46 "Pig farming". 
Financial analysis of the leading organizations (1-4 places in sectoral rating) showed (Figure 1), that even the largest of organizations with revenues of more than 2 billion rubles have unsatisfactory financial condition, and it worsens in the dynamics. Their coefficients of financial independence and investment cover do not correspond to the standard values, and they have a negative value in the coefficient of current liquidity. This is the result of the industry's debts. On January 1, 2017, the investment loan debts in the pig farming totaled 161 219230000 rubles or $48 \%$ of all investment loans in livestock.

\section{Conclusion}

The analysis confirmed the influence of the organizational component (size of the organization, specialization, and form of management) of the organizational and economic mechanism on the investment process.

\section{References}

1. TestFirm, Comparing financial state of a firm (https://www.testfirm.ru)

2. All-Russian classifier of economic activities (http://новыеформы.pф)

3. InfoLine, Agricultural and industrial complex of Russia in 2016 (Moscow, 2017) 